This is the author(s) personal version of the manuscript, as accepted after the review process but prior to final layout and copyediting by the publisher. The final version is published as:

Budd, K., Kelsey, D., Mueller, F. \& Whittle, A. (2018). 'Metaphor, morality and legitimacy: A critical discourse analysis of the media framing of the payday loan industry', Forthcoming in Organization.

Readers are kindly asked to use the official publication in references. 


\section{METAPHOR, MORALITY AND LEGITIMACY: A CRITICAL DISCOURSE ANALYSIS OF THE MEDIA FRAMING OF THE PAYDAY LOAN INDUSTRY}

\section{INTRODUCTION}

In the wake of the global financial crisis, the finance sector as a whole has experienced a dramatic shift in legitimacy (Kelsey et al., 2017; Engelen et al., 2012). Banking had previously been a relatively well-respected profession. The financial crisis triggered a sudden shift in the societal attitudes towards the institutions and its workforce (Whittle \& Mueller, 2012; Tourish \& Hargie, 2012; Stanley et al., 2014). We know that organizations can be problematized in many ways through the expression of concern about their efficiency, effectiveness and ethics (Vaara \& Tienari 2008). The focus of this paper is on the latter and we seek to understand the social construction of moral problems concerning organizations in the news media. According to Vasterman (2005: 511), the news media "manage the public debate and perform the role of the critical watchdog, revealing problems, threats, failures and scandals." The news media thus fulfill an important framing role (Entman, 1993, 2004, 2007; Scheufele, 1999) that can include the framing of organizations as a source of 'problems' affecting society (Street, 2010: 35).

The process through which a 'problem' is socially constructed is known as problematization. In some industries, such as the tobacco industry (Prasad et al., 2016) and nuclear power (Patriotta, Gond \& Schultz, 2011), the problematization process has stretched over decades and the mass circulation media also played an important role in both cases. While the literature on delegitimation has pointed to the role played by moral problematization, we do not yet know how discourse generates moral problems and how this discourse relates to the ideological context of its production and circulation. In addition, we know that industries often gain notoriety in no small part through negative media coverage, but we do not yet fully understand how media discourse enables the framing of organizations as illegitimate. Moral problematization can of course also occur in non-mediatized ways. Actors can engage in moral problematization discourse without engaging the mass media, such as the discourse generated within and between religious organizations, civil society 
organizations or in the political sphere about problematic business practices. However, we focus here on mediated discourse because of our interest in the role of media framing in the construction of moral panics. More specifically, we examine the role played by metaphors in the framing of paydays lenders in the British press, between early 2008 and late 2014 . We ask: how do metaphors contribute to the framing of organizations as illegitimate? While our study is focused on the payday loan industry, our theoretical contribution is of relevance to studies of delegitimation more generally by advancing the understanding of the process through which an organization or industry is constructed as a 'moral problem'.

The paper draws upon and contributes to the theory of moral panics (Cohen, 1972; Welch et al., 2002; Goode \& Ben-Yehuda, 2009) and framing in mass media (Couldry \& Hepp, 2018) by explicating the role played by metaphorical language in these processes. Our study reveals two moral framing functions performed by metaphors. The first framing function involves the creation of analogies with domains that have a pre-existing moral quality due to their association with elements such as pain, pollution, death and disease. The second framing function involves the attribution of agency within which moral responsibility is ascribed to the organization(s) and agency is removed from other actors. We will show how this metaphorical discourse constituted an important building block in the construction of a moral panic that quickly engulfed the media, politics and civil society. We will also discuss the broader implications of our findings in relation to the ideological context and consequences of the moral panic. We will argue that the discourse served the ideological purpose of scapegoating a small section of the finance industry whilst deflecting criticism away from broader underlying socio-economic issues, including the decline in real wages, austerity and reform of the banking system. In so doing, we seek to contribute to the understanding of both the discourse of debt and the financial services industry specifically, and also the understanding of how discourse plays a role in the delegitimation of organizations more generally.

The paper is structured as follows. We begin with a review of the history of morality and debt and a review of the literature on legitimacy, morality and moral panic. This is followed by another literature section on metaphors, media discourse and delegitimation. The empirical context of payday loans is then presented followed by a description of the methodology used in the study. The empirical data is presented in four sections structured 
around the four root metaphors uncovered in the study. We then broaden out the analysis to discuss the wider ideological context and consequences of the discourse. The paper ends with a conclusion and implications for future research.

\section{MORALITY AND DEBT}

Throughout history, there have been competing discourses of the (im)morality of debt (Lazzarato, 2012; Aldohni, 2013) and the consumption associated with borrowing (Trentmann, 2016). As Graeber (2014) has pointed out, debt is a moral category that taps into broader cultural beliefs about the rights, responsibilities and obligations of lending and borrowing. It is certainly not clear-cut or self-evident that borrowers or lenders are either generally 'good' or 'bad'. Indeed, the discourse of moral responsibility for debt is a complex one because there are deep-rooted cultural associations drawn from historical discourses of debt (Graeber, 2014) in addition to a more contemporary discourse concerning the role of debt in neo-liberal capitalism at the level of the individual, organization and nation-state (Lazzarato, 2012).

Much of the moral discourse surrounding debt can be traced back to its roots in religion (Atwood, 2009: 44; Aldohni, 2013; Dickson \& McLachlan, 1989). At one extreme, Aldohni (2013: 424) notes that religious prohibition of moneylending was "due to the exploitative nature of usury which contradicted their underlying moral message". At the other end of the extreme, it was the debtor that was held to be morally responsible for their condition. During certain historical periods, unpaid debt was treated as a crime that was punishable by imprisonment (Peebles, 2013). Moral reasoning operating through discourses of debt at times emphasised that money borrowed should be repaid, casting the debtor who defaults as the immoral party. For example, Weber (1967: 48-54) discusses Benjamin Franklin, who emphasised the acceptability of money lending and cast scorn on those who failed to live a frugal life and resorted to borrowing rather than saving for necessary purchases (see also Dickson \& McLachlan, 1989).

To further complicate matters, discourses of indebtedness are also infused with ideas of 'good' and 'bad' forms of debt and 'good' and 'bad' reasons for getting into debt (Penaloza 
and Barnhart, 2011). Moral differentiations are often made between different types of debt and different types of borrower and lender. There is a long-standing argument in economic geography about different ecologies of borrowers, for example the middle class suburban low risk borrower on the one hand, and the inner city high-risk borrower on the other hand, which has led to different financial products serving each (Leyshon et al., 2004, 2006). Lending to business is also subjected to a different set of moral evaluations to consumer lending. For example, in recent years banks have been criticised for not lending enough of the "muchneeded finance" to small businesses necessary for economic recovery (The Sunday Telegraph, 27 May 2012). In contrast, during the fall-out of the global financial crisis, banks were criticised for lending too much to certain types of consumers and businesses. Within consumer borrowing, a range of moral differentiations also exist. Some forms of borrowing are typically viewed as acceptable or sometimes even praiseworthy (such as mortgages or student loans), whereas other forms are typically viewed as less acceptable and disreputable (such as the use of pawnbrokers, logbook loans secured against vehicles and rent-to-own) (Graeber, 2014).

Payday loans are a high-cost credit product in which loans are made on a short-term basis, usually for a relatively small amount, to be repaid on the next 'payday'. While 'payday cheque cashing' services have a long history, the more recent variant makes use of digital technology to advance short-term loans at the click of a button. Whilst the sector forms part of the wider high-cost credit market (Leyshon et al., 2004, 2006), payday loans have undoubtedly become "its most notorious and well-known variant" (Packman, 2014: 2). Payday lending is a type of high-interest lending that includes "legal loan sharking" which emerged as part of a "conceptual evolution" in sub-prime lending practices (Aldohni, 2013: 423-4). Thus, whilst payday loans are nothing really new, the sudden and intense emergence of a problematizing discourse targeting the payday loan industry has been a relatively recent phenomenon and hence is the focus of this paper.

\section{LEGITIMACY, MORALITY AND 'MORAL PANIC'}

To state that an organization or industry has legitimacy is to acknowledge that it has achieved a level of acceptance within society. Such acceptance is negotiable and not necessarily 
permanent. Therefore, organizations need to engage in ongoing discursive processes of building, maintaining and repairing legitimacy. Vaara and Monin (2010) argue that the use of discourse to construct legitimacy is not just a symbolic 'sideshow' but is central to how organizations interact with societies and its stakeholders. From this discursive perspective, legitimacy is not something that organizations 'have' by possessing certain attributes or 'bases'. Rather, legitimacy is viewed as an ongoing and dynamic discursive sensemaking process (Vaara and Monin, 2010). Legitimacy is also thought to be established through discourses that provide the 'frames' through which people make sense of particular issues (Vaara and Tienari, 2008). These discourses may be homogenous or heterogeneous, stable or changing, and accepted or contested over particular periods of time and in relation to specific issues or events (Phillips and Hardy, 1997; Suddaby and Greenwood, 2005; Patriotta, Gond \& Schultz, 2011). Thus, organizations that were previously legitimate can be subject to periods of delegitimation or, like in our case, organizations that have previously experienced a morally problematic status can be subjected to further intensification of that problematization, either because of particular dramatic events such as scandals or because of more general and diffuse shifts in societal attitudes.

The taint of illegitimacy can affect individual organizations but can also spread to groups of similar firms or even whole institutional fields (Jonsson et al., 2009). Industries and occupations that were previously highly regarded can be subject to sudden losses in legitimacy, such as the investment banking industry following the financial crisis (Stanley et al., 2014). Hudson (2008: 252) claims that there are also certain bodies of organizations, which lose social support and "suffer broad-based social condemnation". As we noted the start of this paper, moneylending is one such industry with a long-standing history of illegitimacy, such as the condemnation of usury during the European Middle Ages (Graeber, 2014). Importantly for our purposes, shifts in legitimacy can affect not only organizations that were previously legitimate but also organizations that have long-standing associations with illegitimacy (such as the sex industry or gambling industry) which then experience periods of increased (or decreased) media attention and public scrutiny relating to the social or moral problems they are deemed to generate.

The concept of problematization is a vital component in understanding shifts in legitimacy. Problematization is used here to refer to a rhetorical strategy for constructing a 
particular practice or actor as a 'problem' and is often, but not always, coupled with ideas purporting to be a 'solution' to that problem (Toulmin et al., 1979). Problematization is a concept that has also been used in scholarship inspired by actor-network theory and science and technology studies (Lowe and Roper, 2000; Lowe, 2001; Ureta, 2014), as well as poststructuralist theory, particularly the work of Michel Foucault (Bacchi, 2009; Barthe, 2009; Marron, 2014; Tregidga, 2013). In this paper, we instead draw on and contribute to the body of work that adopts a discursive approach to studying problematization. Discourses of morality are important here because morality is a key component of (de)legitimation processes (Suchman, 1995; Van Leeuwen, 2007). The moral dimension is also central to Vaara and Tienari's (2008: 986) framework for understanding discursive legitimation processes, which they define as the process of creating "a sense of positive, beneficial, ethical, understandable, necessary, or otherwise acceptable action in a specific setting".

Vaara and Monin (2010: 6) define delegitimation as the process of "establishing a sense of negative, morally reprehensible, or otherwise unacceptable action or overall state of affairs". For example, Vaara et al. (2004) show how 'problematization' was used in discourses of airline alliances to question the value of traditional nationalistic strategies and to pave the way for the 'naturalization' of alliances as a legitimate business strategy. However, problematization can also occur in the absence of a ready-made solution being put forward, as part of a more general and diffuse construction of something being 'wrong' or 'damaging' to society. It is in this sense that the media often plays a role in acting as the 'moral compass' or 'moral watchdog' of society (Wilkins \& Coleman, 2005) and by creating a 'moral panic' around particular issues (Cohen, 1972).

The concept of 'moral panic' was first developed by Cohen (1972) based on his study of media coverage of mods and rockers. The concept of moral panic is now a central concept in the sociology of deviance and media studies (Goode and Ben-Yehuda, 2009). The concept refers to the manufacturing of an exaggerated fear about a particular social group that are presented by critics as behaving in 'immoral', and potentially but not necessarily, illegal, ways. These moral panics create and sustain an image of a 'folk devil' (Cohen, 1972) that concentrates the moral fears of society. A 'moral panic' occurs when "a condition, episode, person or group of persons emerges to become defined as a threat to societal values and interest; its nature is presented in a stylized and stereotypical fashion by the mass media; the 
moral barricades are manned by editors, bishops, politicians, and other right-thinking people." (Cohen, 1972: 9) Crucially for our purposes here, moral panics also have an ideological component. As Goode and Ben-Yehuda (2009: 47) argue, when examining those behind the manufacturing of the moral panic, it seems that "the individuals who took up the cause, and worked to criminalize the behaviour in question, were motivated not by the harm inflicted by the behaviour itself, but by moral, political, economic, and ideological issues."

By creating a major fuss about trivial or non-existent problems, ideological effects are also created when the problems created by elites are side-lined in public consciousness and removed from the political agenda. Statements of the harm created by some important issues, such tax avoidance, are ignored, dismissed or reserved for selected audiences, while the discourse of the harm created by another, perhaps more trivial issue, such as MPs' expenses, "quickly becomes the topic of widespread public concern, hostility, outrage, denunciations, investigations, legislation, campaigns, a flood of media attention, [and] social movement activity" (Goode and Ben-Yehuda, 2009: 79). For our purposes, it is important to emphasize that we study the discursive practices through which the media "'fan public indignation' and ... 'engineer' moral panics to generate news and appeal to the concerns of their audiences" (Young, 1971: 90). Whilst we cannot judge the effects these articles would have had on their readers, we agree with Goode and Ben-Yehuda (2009: 91) that, "even if the media do not generate or stir up fear, concern or hostility in the public, the media's expression of that fear, concern, or hostility is itself a moral panic - a media panic, but a moral panic nonetheless."

The construction of organizations and economic issues in the media has gained increasing attention in recent years from organizational researchers, with scholars recognising the importance of media texts in shaping public opinion on business issues (e.g. Deephouse, 2000; Kostera \& Glinka, 2001; Vaara and Tienari, 2002; Chouliaraki and Morsing, 2010; Hartz and Steger, 2010; Grafström and Windell, 2011; Riaz et al., 2011; Stanley et al., 2014). Pallas et al. (2014a, b) contend that the monitoring, scrutiny and evaluation of organizations by the media form an important grounding for how we understand and evaluate organizations and also shape how organizations themselves respond. Media discourse, argue Gamson and Modigliani (1989, p. 1), "is an essential context for understanding opinion" on different social issues. It is through the media that significant discourses are created, promulgated and refined, in addition to their active role in 'framing' 
debates (Riaz et al., 2011, p. 188). Importantly for our purposes, Scheufele and Tewksbury (2006) argue that media discourse is consequential not only for its role in disseminating information about an issue but also for its role in agenda setting by getting certain issues onto the agenda and framing by shaping how we think about that the issue. Thus, media discourse shapes both whether we think about an issue as well as how we think about it (Scheufele and Tewksbury, 2006: 14).

According to Cornelissen and Werner (2014: 202), the framing literature has shown that frames play a role in diagnosing the causes of problems, proposing strategies to address the problems and mobilizing actors into action to address the problem (see Snow \& Benford, 1988). Different public policy responses also flow from the discourses that gain dominance, as Hardy and Phillips (1999) showed in their analysis of the media discourses about the Canadian refugee system. This is particularly relevant for our purposes here because the media framing of the causes of the 'moral problem' did indeed mobilize policy responses in the form of regulation of the industry. This framing process is also particularly important, we would argue, in situations where (il)legitimacy is not already clear-cut and a variety of justifications can also be put forward that seek to repair in reinstate the legitimacy of a controversial industry (Patriotta, Gond \& Schultz, 2011). In the next section we will expand on the role of metaphors specifically in this framing process.

\section{METAPHORS AND FRAMING}

Our contribution to the existing body of research on discourse and legitimation is through theorising the framing function performed by metaphors in the construction of a moral problem. Metaphor can generally be described as a "phenomenon whereby we talk and, potentially, think about something in terms of something else" (Semino, 2008: 11). Interest in how metaphors frame our understanding of social issues, reinforce existing thinking or provide new ways of viewing a social phenomenon has led to extensive research on metaphor within organization studies (Cassell and Bishop, 2014; Tourish and Hargie, 2012; Cornelissen et al., 2008; Cornelissen, 2005; Oswick et al., 2002; Inns, 2002; Grant and Oswick, 1996; Tinker, 1986). 
The media is a key site in which metaphors are used and circulated. In an early study, Hirsch (1986) examined the metaphors of hostile takeovers in business periodicals, showing how the normative framing of hostile takeovers facilitated the legitimation and diffusion of their use. Crucially, the media not only reflects changes in social attitudes towards business practices, it also plays a key role in creating shifts in legitimacy (Hellgren et al., 2002; Vaara and Tienari, 2002: 297; Risberg et al., 2003; Vaara et al., 2003; Kuronen et al., 2005: 261; Vaara et al., 2006: 806; Riad and Vaara, 2011). Metaphors do of course have many other cognitive, social and ideological functions in addition to moral problematisation and it is also reasonable to speculate that moral problematisation could take place without metaphorical language. However, the two elements do connect in situations where metaphorical language serves to create moral associations in the construction of a situation as 'morally problematic'. For example, in the third edition of his now classic book, Cohen (2011: xxiv) highlights the role of metaphors such as flooding, tides and waves in the creation of moral panics over immigration in the media. The role of metaphors has also been highlighted by others writing about moral panics: Hawdon (2001), for example, highlighted the role played by war metaphors in presidential rhetoric about narcotics, and Welch et al. (2002) explored the role played by metaphors of the 'wild' such as 'wolf pack' in the representation of youth violence in the media.

To develop a more critical approach, metaphor research has started to move beyond the purely cognitive aspects of how metaphors affect perception (Lakoff, 1987; Lakoff, 1993; Lakoff \& Johnson, 1987). A small but growing body of work on critical metaphor analysis has begun to explore the power-laden and ideological nature of metaphor use (Charteris-Black, 2004; Koller, 2005; Lakoff, 2008; Hart, 2008; Semino, 2008). As Semino (2008: 32) highlights, metaphors are not neutral and can serve ideological purposes through the way they highlight certain aspects of the target domain while downplaying or hiding others. Metaphors, like discourse more generally, can serve an ideological purpose by playing down "structural conflicts" and helping to create a "false consciousness" (Tinker, 1986: 363, 378). Metaphors that attain the status of being taken for granted and appear as 'common sense' can appear as neutral while actually carrying power implications (Semino, 2008: 33), as Koller's (2008) analysis of the sexism underlying contemporary business discourse shows. Metaphor analysis can therefore be seen as "central to critical discourse analysis since it is concerned with 
forming a coherent view of reality" (Charteris-Black, 2004: 28) that also serves to reinforce unequal power relations in society (Fairclough, 2001, 2010).

Much of the literature on metaphorical discourse and legitimation has studied how the metaphors serve to legitimate and 'naturalize' (represent as natural and inevitable) particular management ideas and organizational practices (Chiapello and Fairclough, 2002). For example, studies have shown how metaphorical language can be used to make organizational actions appear natural and unavoidable (Kuronen et al., 2005) and to make sense of and justify contentious business decisions (Hellgren et al., 2002; Risberg et al., 2003). Thus, it is clear from this existing research that metaphors can play a significant role at a societal and political level in establishing, or contesting, the legitimacy of organizations and their actions. We also know that this delegitimation process can lead to radical change in the practices of firms, in addition to shaping the actions of governments, regulators and other stakeholders (Vaara et al., 2006). What we do not yet know is how metaphors operate to link the cognitive process of sensemaking about organizations with the social and political process of enacting shifts in industry practices and government policies, including the ideological dimension of these shifts. Our aim is to establish this link by theorizing how organizations are framed as a 'moral problem' through the metaphors employed in the media about payday loans. In the next section, we will provide a brief overview of the rise of the payday loan industry, the topic of this study, including its historical roots.

\section{CONTEXT: THE PAYDAY LOAN INDUSTRY}

Payday lending initially developed in the United States and dates back at least as far as the Great Depression. An early form of payday lending consisted of money being lent to consumers in return for a post-dated cheque, for the amount plus interest and other fees, which would later be redeemed by the lender (Packman, 2014: 5). In the UK, payday lending also began in pawnbroking and cheque-cashing shops. By 2014, there were approximately 1,800 retail stores offering payday loans as part of their services (ACCA, 2014: 10). Both the in-store market and the door-to-door lending market (Leyshon et al., 2004, 2006) have been gradually superseded by online payday lenders, which are now responsible for issuing around two thirds of short-term loans in the UK. The payday loan industry has grown rapidly in a short period of time, from an estimated $£ 900$ million in $2008 / 09$ to over $£ 2$ billion in $2011 / 12$ (Office 
of Fair Trading, 2013: 9). These figures are, however, still a small fraction of the $£ 200$ billion consumer credit market, which includes other types of unsecured debt such as credit cards and overdrafts (Financial Conduct Authority, 2014). The retail side of the payday loan industry is dominated by two American companies, Dollar Financial (which owns The Money Shop) and Axcess Financial (which owns brands including the Cheque Centre). The two largest onlineonly operators, Wonga and Cash America (owner of Quick Quid), account for nearly half of the entire payday loan sector, despite having only been operating in the UK since 2008 (ACCA, 2014: 10).

Payday loans tend to be taken out by those with a poor credit history and limited access to other loan products (Aldohni, 2013: 421). Payday lending therefore tends to be categorized with other 'alternative' lending outlets such as pawnbrokers, doorstep lending and logbook loans (Financial Conduct Authority, 2016) which tend to charge high interest rates and target at those at the periphery of the mainstream banking industry (Aldohni, 2013). An investigation by market regulators in the UK in 2013 found that approximately one third of payday loans are "repaid late or not repaid at all" and loans that are "rolled over or refinanced at least once" made up a significant source of revenue for lenders (Office of Fair Trading, 2013: 2). According to the UK Competition and Markets Authority (2015), borrowers are predominantly male and of a younger than average age, work full-time and have average income levels. Over half of borrowers reported that the payday loan was used to fund essential living costs or an unexpected rise in expenses. Many were repeat borrowers who often returned to the same lender to obtain credit at a later date (Competition and Markets Authority, 2015).

In recent years, payday loan companies have been criticised for charging excessively high rates of interest, encouraging people to renew loans and take out additional borrowing and for using deceptive marketing practices. Payday lenders have been described in the press as a "plague" (Mail on Sunday, 12 May 2013), "toxic" (The Sun, 17 Oct 2012), "corrosive" (The Guardian, 13 Mar 2014), "ruthless" (Metro, 29 Feb 2012), "abusive” (The Guardian, 6 Mar 2013), "parasites" (The Mirror, 4 Nov 2010), and a "scourge" on society (Mail on Sunday, 12 May 2013). If we accept a definition of legitimacy as "a generalized perception or assumption that the actions of an entity are desirable, proper, or appropriate within some socially constructed system of norms, values, beliefs, and definitions" (Suchman, 1995: 574), payday lenders had clearly experienced an intense period of delegitimation (Durand \& McGuire, 
2005). Unlike organizations that previously experienced high levels of legitimacy and then experience a sudden period of delegitimation, often following a particular crisis or scandal (Patriotta, Gond \& Schultz, 2011), payday lenders obviously did not start out with a 'clean slate'. As our review of the history of discourses of debt earlier in the paper has shown, moneylending and especially sub-prime moneylending has a long history of moral problematization. However, in terms of a mediatized discourse that reached the public consciousness and political agenda, while some early reports did pose questions about the high interest rates being charged in the home credit and door-to-door lending sector (Leyshon et al., 2004, 2006), there was no concentrated problematization of the industry in the mass media. Hence, the focus of this study is on the sudden and intense period of coverage that built the sense of a 'moral problem' in the mass media.

\section{METHODOLOGY}

For this study, a body of texts from the Nexis database were selected from high-circulating newspapers that encapsulated 'popular' discourse on the topic of payday lending. After consulting the National Readership Survey figures, the top six titles (and their Sunday counterparts) were selected for inclusion (see Figure 1).

\section{--- Insert Figure 1 here ---}

Together, the six titles selected have print and online readership that reaches over 12 million readers per month on average. The sample encapsulates a range of political perspectives, a range of formats (tabloid and broadsheet) and a range of price points (paid for and freesheet). The Nexis search revealed that payday lending was only mentioned in newspaper reports dating from 2008 onwards. The sample therefore begins on 1 January 2008 and ends on 31 December 2014, the point at which regulation of the industry had been announced by the government. All variations of the main search term were included in the database search, including: payday loan(s), lender(s) and lending. To limit articles to those of the highest relevance, the 'Major Mentions' function in Nexis was used, selecting only those articles that featured the search terms in the headline, lead paragraph or indexing. $40 \%$ of the articles in 
the data-set were classified as news articles, the rest being opinion-led articles such as editorial columns, letter pages and feature articles. The first front-page article, indicating the increasing 'public interest' and 'newsworthy' status of the topic, was in The Metro in 2010.

The dataset comprised 1,693 articles over the 7-year period (2008-2014). The majority of the sample dated from 2012-2014, when media reporting about the industry was at its peak (see Figure 2). The study included analysis of both the discourse of the journalists and those sources and commentators they cited and Figure 3 gives an overview of the sources directly quoted in the articles.

--- Insert Figure 2 here ---

--- Insert Figure 3 here ---

A random sampling method was used for the three years where the sample was largest $(2012,2013$ \& 2014) that involved selecting ten articles at random from each month using a random number generator to enable a dataset to be generated that was amenable to qualitative analysis (see Table 1).

--- Insert Table 1 here ---

The decision to analyse metaphors arose from the first stage of qualitative coding, in which a prevalence of metaphorical expressions was identified. Each article was then coded line by line to identify metaphorical expressions, a method also used by other organizational scholars such as Tourish and Hargie (2012). We developed our own thematic categories using an inductive approach (Grant and Oswick, 1996: 10). Our analysis started by creating categories using NVivo to organize the material thematically, with categories revised and reworked as the process went on (Jørgensen and Phillips, 2002). This resulted in five thematic categories: Predators/Parasites, Orientation, Warfare, Pathology/III-health and Other. The category 'Other' has been excluded from this paper due to the diverse nature of the metaphors used, often 'dead' metaphors relating to commonplace figures of speech (Cornelissen, Kafouros \& Lock, 2005). Crucially, the analysis was guided by the need to avoid just 'spotting' metaphors (Czarniawska, 2004: 41). Instead, we looked for systematic patterns in metaphor use that 
seemed to play an important role in the social construction of mediated reality (Couldry \& Hepp, 2018). The findings are presented in four sections following the four thematic categories of metaphors uncovered in the study followed by a discussion of the framing function they perform in the construction of a moral problem and finally a discussion of the wider ideological function we propose was being served by the discourse.

\section{THE DISCURSIVE CONSTRUCTION OF A 'MORAL PROBLEM'}

Despite the different formats, audiences and political leanings of the newspapers we studied, all the newspapers identified the payday loan industry as a 'moral problem'. It was during the qualitative analysis of this 'problematization' discourse that the study found that problematization was being undertaken not only through rational argument and evidence (although this was present), but also through the use of metaphorical language. Four root metaphors were identified during the coding of the data. Table 2 provides an overview of the frequency of the four root metaphors across the dataset.

--- Insert Table 2 here ---

As Table 2 shows, the use of metaphors to perform problematization straddled the political spectrum, including both left-leaning and right-leaning papers and both tabloids and broadsheets. Contrary to Goatly's (1997: 302) argument that so-called 'serious' newspapers avoid such metaphorical language, this study found only small differences between the broadsheets and tabloids ${ }^{1}$. We will now discuss each root metaphor in turn.

Predators and parasites The most common set of metaphors in the dataset were organized around the root metaphor of predators and parasites, as summarised in Table 3.

$$
\text { --- Insert Table } 3 \text { here --- }
$$

'Loan shark' is a commonplace metaphor used to describe certain types of illegal lenders that charge high interest rates to those excluded from mainstream finance (Aldohni, 2013). In some cases, as shown in Table 3, a kind of 'categorical comparison' was used: payday lenders were characterised as similar to illegal loan sharks through the use of terms such as

\footnotetext{
${ }^{1}$ This finding is in line with Lule (2001), who found widespread metaphor use in the culturally elite New York Times.
} 
"legal loan shark". However, examples of 'categorical conflation' were also found, where payday lenders were not compared with illegal loan sharks but conflated into that category. Just as organizations gain legitimacy and resources from fitting into or aligning themselves with categories (Zuckerman, 1999), here we found that the organizations were delegitimated by being placed into an already established illegitimate category. The vulture metaphor also played on cultural tropes derived from the natural world concerning fear of death. With vulture metaphors, payday loan firms were cast as 'feeding off the dead', where 'feeding' is a metaphor for profiting, and 'the dead' represents the borrowers, who are cast as the victims. The final metaphor type was of parasites and leeches, casting the industry as a pest that infects and feeds off its victims. These metaphors performed a framing function by presenting the payday loan firms as a dangerous and bloodthirsty creature, a scavenger that feeds off carcasses or a parasite that feeds off its host. Together, these metaphors problematised the lenders by generating images of danger to life and threat to the body.

Orientation The second most frequently used set of metaphors were organized around the root metaphor of orientation, as summarised in Table 4.

--- Insert Table 4 here ---

The first type of orientation metaphor involved descriptions of an upward or outward movement. Here, borrowers were presented as being powerless to stop debt 'building up', 'mounting up' or 'spiralling' out of their control. Crucially, it was not the borrower being described as responsible for causing the upward or outward movement, but rather the debt itself. In one story concerning a suicide, the 'spiralling' of debt was identified as a causal factor and the active agent was the debt itself rather than the decisions or (in)actions of the borrower. These upwards or outward metaphors characterised borrowers being acted upon by the debt and not personally responsible for their debt. Agency here was taken away from borrowers and given to an abstraction. The second set of orientational metaphors characterised the payday industry itself as 'rocketing', 'exploding' and expanding at 'breakneck' speed, which served to problematise the growth of the industry as being dangerously out of control. The third type of orientational metaphor was of downwards movement. Rather than 'spiralling out' of control, borrowers were presented as 'spiralling down' or 'falling into' debt. This framing also took agency away from the borrowers and cast 
them as being subject to physical forces beyond their control. Agency was instead discursively attributed to lenders, who were portrayed as 'pushing' or 'sucking' people into debt. The final type of orientational metaphor drew on ideas of being trapped or unable to move. Borrowers were presented as being unable to get out of a 'hole', being 'locked in', trapped in a 'web' and being weighed down or 'saddled' with debt. The moral problematisation achieved by these orientation metaphors is distinct from the predator and parasite metaphors because it involves attribution of responsibility for the debt to the lender and removal of agency from the debtor.

Warfare The third most frequent set of metaphors centred around the root metaphor of warfare, as summarised in Table 5.

\section{--- Insert Table 5 here ---}

Our study found a cluster of terms drawn from associations with invasion, violence and battles. The use of invasion metaphors created an image of payday lenders advancing into new territory and bringing destruction in their path. In particular, the invaders were framed as "foreign" - described as either 'global', 'overseas', or, more specifically, 'American'. These metaphors of foreign invasion exemplify the kind of 'banal nationalism' described by Billig (1995), evoking images of an embattled nation having to fight off threats from foreigners. Lenders were also described as 'attacking' consumers using terms such as 'hitting', 'slapping' and 'bombarding'. An image of a moral battle was also invoked when the newspapers discussed the 'fight back' against the lenders. These metaphors formed part of a moral plotline of 'good versus evil' (Hartz and Steger, 2010). Lenders were described as 'taken on' in a fight with a 'charge' being led against them. Lenders were described as subjected to a 'battle' and 'attack' from opposing forces for good. The 'good' was invoked through references to heroic characters, such as Labour politician Stella Creasy, religious figures, charities, and regulators. The framing role undertaken by these metaphors involved the representation of the lenders as aggressive foreign invaders who created destruction in their path, coupled with a plot-line of a moral battle of forces of good against evil. Lenders were thereby problematised as an enemy of the people that required an opposition force to counter their dark and destructive forces. 
Pathology The final set of metaphors were organized around the root metaphor of pathology and ill-health (see also Semino, 2008: 104), as summarised in Table 6.

--- Insert Table 6 here ---

Borrowers were described as 'hurt', 'feeling pain', 'stung' and 'bled dry' as a result of the actions of payday lenders. Lenders were also described as inflicting pain by 'drilling', 'crippling' and 'squeezing' borrowers through their actions. In the story mentioned earlier, a payday loan was also singled out as being responsible for the death of one borrower who committed suicide. Other metaphors invoked images of payday lenders as dangerous to public health. Lenders were described as an 'epidemic' and 'plague', invoking images of an out of control outbreak of disease that was wreaking havoc and misery on society. Lenders were described as 'toxic', however in some variants the source of this 'toxicity' was attributed to the economic policies of the previous Labour Government under Gordon Brown. Borrowers were warned about the dangers of payday loans, being advised to keeping a distance with a 'bargepole' and calling for 'health warnings' on the products like those used on cigarette packets. The toxicity metaphor was also used as a contrast by alternative lenders who presented themselves as the 'antidote' of payday lenders, invoking images of a cure to a venomous attack. Lenders were also described as 'addictive', invoking images of addictive drugs that served not only to highlight the danger to health but also to remove personal responsibility away from borrowers who needed help to overcome their 'addiction'. Through these pathology metaphors, lenders were framed as the cause of pain and suffering and problematization was undertaken by the representation of lenders as harmful to borrowers and society at large.

\section{DISCUSSION}

To discuss the significance of our findings for theory development, we will first discuss what our study contributes to the theory of discursive delegitimation by identifying the framing role of metaphors in the social construction of a 'moral problem'. Secondly, in line with the critical approach to discourse analysis we adopt (Chilton, 2004; Hart, 2008), we will then broaden out the discussion to consider the ideological context and consequences of moral 
problematization discourse in relation to the creation of moral panics and the socioeconomic and political functions it performs.

\section{Metaphors, Morality and Problematization}

This study has found that four root metaphors were used to characterise the payday loan industry in the British press. How did these metaphors perform moral problematization through the framing of a 'problem'? Our study has found two framing functions that help us to understand how metaphors perform moral problematization that have a broader relevance beyond our industry-specific case. The first framing function works to construct a sense of the damage or harm that has been generated by the actions of the organization by creating cognitive associations (Koller, 2005), in our case associations with pain, pollution, death and disease. Van Leeuwen (2007) argues that analogies problematize through comparison with other domains or activities that are already imbued with negative values or immoral qualities through their association with pain or suffering. Van Leeuwen gives the example of critiques of compulsory schooling using metaphors such as 'drilling' and 'incarcerating'. In the metaphors of payday loans we have studied here, the domains of warfare, pathology and predators all brought with them a particular "symbolic-moral universe" (Ben-Yehuda, 1990: 3) that served to problematize the industry. In our case, warfare metaphors conjured up images of the industry as a foreign enemy that was inflicting violence on society, also drawing on notions of a moral struggle between good and evil. IIIhealth metaphors conjured up images of the industry inflicting pain and administering toxins on people. Predator metaphors conjured up images of fear of death from predatory attacks, parasitic invasion of the body, and organizations that feed off the misfortune of others. Importantly, payday loan firms were not only compared with, but sometimes also conflated with an illegal industry through the use of the term 'loan sharks', conjuring up images of the kinds of illegal operators who, according to popular cultural beliefs, readily resort to intimidation or violence if debtors do not pay.

The second framing function of metaphors involved the attribution of agency which served as a crucial component in the reasoning about moral responsibility. Orientation metaphors played an important role here specifically. Contrary to the idea in metaphor research that 'up' is normally associated with something positive and 'down' is normally 
associated with something negative (Lakoff and Johnson, 1980: 14-15; Lakoff, 1990: 276), the same was not true for the discourse of debt. While downward metaphors were indeed associated with being negative for the borrower, upward metaphors were also associated with debt piling or mounting up. The moral problematisation performed by orientation metaphors was drawn from images of borrowers being trapped, contained, saddled down, locked or pushed into debt. Crucially, it was the firm that was described as the agent causing these 'bad' things to happen, not the borrower who applied for the loan.

These metaphors played an important role in shaping the moral reasoning of the discourse because conceptions of morality are typically grounded in reasoning about responsibility. For instance, actions would not normally be ascribed any moral significance if they are characterised as involving chance, luck, or factors beyond the control of those involved (Frye, 1957; Davidson, 2001), in other words if there is very little choice or agency contained in an action (Whittle and Mueller, 2016). According to common sense moral reasoning, if the actor had free and unconstrained choice (i.e. agency) and that choice led to a negative outcome for others, the actor should then be held morally responsible (Harré, 1995; Harré and van Langenhove, 1999). For actors who had no choice or severely constrained choice, moral responsibility is not typically attributed.

The attribution or removal of agency is significant in our study because the discourse we studied characterised payday loan debt as something that happens to, or is done to, borrowers rather than something being done by them. This removed the kind of moral reasoning that would lead to the conclusion that borrowers chose to apply for a loan and therefore should be held responsible for the consequences. For example, war metaphors presented the industry as the agents and instigators of a violent attack. Health metaphors presented the firms as agents causing the pain and suffering, not as a self-inflicted or selfinduced phenomenon. Predator and parasite metaphors presented the lenders as inflicting death or suffering on the borrower, removing responsibility from the borrower. Orientation metaphors presented the borrower as subject to forces outside their control and being trapped and unable to escape. While Tourish and Hargie (2012) show how the metaphors used by bankers sought to minimise their responsibility for what happened in the global financial crisis, our study has shown how attributions of agency serve to maximise the responsibility of the payday lenders but minimise the responsibility of the borrowers. 
The role played by metaphors in this discursive attribution process also has wider relevance beyond the payday loan context to the study of the problematization of other firms and industries. Gambling firms, for example, have recently been targeted for criticism on the basis of their responsibility for 'luring' gamblers into incurring heavy losses, placing agency in the hands of the firms and removing agency from the consumer. The theoretical contribution of our study therefore lies in advancing the understanding of how metaphorical language plays a role in ascribing or removing agency, thereby laying out a moral landscape in which blame for the 'problem' can be attributed. Furthermore, the construction of a 'moral problem' is the first step in the construction of a moral panic that requires us to understand the ideological functions these moral panics play in society, a point we will discuss further in the next discussion section.

\section{Moral Panic, Policy Responses and Ideology}

The mushrooming of 'moral panic' (Goode and Ben-Yehuda, 2009) and 'media hype' (Vasterman, 2005) about payday loans that we have traced in this study not only reached public consciousness, it also hit the policy agenda. The high interest rate doorstep lending industry existed already in the 1990s and 2000s. In 2004, Leyshon et al. (2004: 643) advised "that an effective route for public policy in this area would not be to regulate the home credit industry out of existence" (our emphasis). Sub-prime lenders play an important role in providing access to credit to those excluded from mainstream banking services. What changed between then and now? Attempts to regulate high interest rate lending are certainly not new. In 2005, for example, an 'early day motion' in the House of Commons aimed at regulating this sector was unsuccessful, in spite of prominent backers (Aldohni, 2013: 422). In 2011, the Consumer Credit Bill, a Private Members bill, which aimed at limiting interest rates and charges, failed to complete its passage through Parliament before the end of the session (Aldohni, 2013: 423). However, ongoing concerns over poor practices within the industry led to investigations being carried out by regulators, who cited evidence of "irresponsible lending" by firms (Office of Fair Trading, 2013: 3). By 2013, the issue was again firmly on the political agenda and in January 2015 the government announced new regulation that enforced more stringent affordability checks, risk warnings on advertisements, set a legal limit on the rate of interest and other fees that could be charged and limited the number of times 
loans could be rolled over (Financial Conduct Authority, 2014). Similar calls for government intervention in the market have also been made in other countries around the world at the time of writing, indicating a more global trend of problematization of the industry (The Guardian website, 1 March 2017).

The effects of the industry's problematization were not limited to state intervention. Such was the extent of the moral taint that other actors severed ties with payday firms, as was demonstrated with the uproar from fans and local residents over Wonga's sponsorship of Newcastle United Football Club (The Guardian, 10 Oct 2012). Church leaders and charitable organizations led the campaign to establish more 'ethical' lenders, such as credit unions. This counter-discourse sparked debates that included challenges to dominant neo-liberal ideas that only markets can solve major social problems such as inequality and poverty (Crouch, 2011). The payday loan firms themselves sought to voluntarily change their practices before the regulation eventually came into force. Trade bodies representing the industry also showed they were acting proactively to tackle the 'problem', with four bodies joining together in 2012 to draw up a Customer Charter, to which 100 lenders representing $90 \%$ of the market signed up (The Guardian, 25 Jul 2012). From a critical standpoint, however, these industry reactions could also be viewed as tactics to create the impression that self-governance was effective and regulation was therefore unnecessary. It is therefore reasonable to conclude that the discourse we have analysed had a material as well as symbolic impact on both organizational practice and government policy (Fairclough, 2010: 96).

The media was significant in this problematization process both in reporting the actions of politicians, campaigners and other stakeholders, as well as influencing the discursive landscape through their coverage. The media contributed firstly to the framing of the industry as a 'moral problem' and, secondly, in whipping up the 'moral panic' that policymakers and regulators then sought to address (Gamson et al., 1992; Vasterman, 2005; Goode \& Ben-Yehuda, 2009). By explaining how problematization takes place through metaphors, we demonstrate the broader theoretical significance of adopting a critical approach to metaphor analysis (e.g. Chilton, 2004; Hart, 2008). In so doing, we connect work in organization theory to work in politics and public policy contexts, where critical metaphor analysts have begun to ask questions about which metaphors are used, why they are chosen and the social impact that metaphors have in framing public policy choices (Charteris-Black, 2014, Ch 8). 
It is possible to view this discourse of moral panic as an example of the emergence of a counter-discourse that serves to contest the neo-liberal agenda and justify a shift in government policy towards state intervention in markets. However, we propose that this interpretation misses the key ideological role that this discourse served in the socio-economic context at the time of the study (2008-2014). During this period, the progressive deregulation of the banking sector over the previous two decades was identified as a significant factor in the chain of events that led to the global financial crisis (Stiglitz, 2010). The moral problematization of payday lenders took place alongside a wider erosion of trust in the finance sector as a whole, following scandals involving audit failure, sub-prime lending, Liborrate rigging, PPI mis-selling and, more recently, lending to SMEs (Gillespie and Owen, 2013; Mueller et al., 2015). Increased state regulation of the banking sector was therefore gaining traction in public discourse (Engelen et al., 2012). Governments all around the world were also being held accountable for their public policy choices both in terms of handling the debt burden they were left with and plans for avoiding another similar crisis in future (Riaz et al., 2012).

In this context, governments were under pressure to give the appearance of a display of strength against the finance sector, which was becoming seen as a 'pariah' on society, especially in the years of austerity measures that followed (Kelsey et al., 2017). How, then, does the moral panic about payday loans fit into this ideological landscape? The scapegoating of certain agents (Giger \& Nelson, 2011), be they groups or a sector, can serve the ideological purpose of deflecting from a more fundamental or encompassing critique. Indeed, instead of seeking to "project a coherent alternative to neo-liberalism" (Block, 2000: 84), our study found newspapers proposing much more localised forms of critique that singled out one small section of the finance sector (representing $1 \%$ of the consumer credit market) for intervention and reform. We therefore propose that the ideological role of the moral panic was to ensure localized critique against sections of capitalism which might well serve to protect the system as a whole from critique (Chiapello, 2013). For newspapers of all leanings, but especially for the political right not normally associated with radical critique of capitalist structures, the coverage enabled that to present themselves as fighting causes that would benefit ordinary working people and against the worst excesses of capitalism, avoiding discourse that questioned the wider system as a whole. 
Within the political sphere, a moral crusade that started off at the political left (most notably through the campaigning of Labour MP Stella Creasy) was taken up by the ruling Conservative government who enthusiastically jumped on the bandwagon and translated the moral outrage into legislation. We would argue therefore that our study provides a powerful example of "the distinctive generative power of text" (Fairclough, 2010: 173) by showing how discourse plays a constitutive role in setting the moral argument for not only public outrage but also state intervention in markets (Engelen et al., 2012). Importantly, in this case, state intervention came from a ruling Conservative government strongly associated with neoliberal policies and not known for attacking free markets and 'wealth-creators'. There are certainly convenient ideological benefits from appearing to be 'on the side' of those experiencing financial hardship and struggling to make ends meet at the same time as austerity measures and an economy in recession were hitting the poorest members of society the hardest. While we cannot make claims from this study about a precise causal link, given the fact that the media both report on politics as well as influencing politics, it is nonetheless clear that the state intervention in the payday loan market was closely tied to the construction of the moral panic whipped up in the media.

While newspapers did at times make the move from episodic stories to more thematic issues (Ritchie, 2013: 107)², for example by linking stories about payday loans to the broader decline in real wages and effects of austerity, the media discourse remained largely focused on the 'witch hunt' (Goode \& Ben-Yehuda, 2009) directed towards the industry itself. Why does this matter and what is the theoretical significance? According to Lowe (2001), problematization plays a critical role in enabling the mobilization of policy responses of various kinds. Whilst others have argued that different problematizations lead to different policies (Vallgarda, 2008), we propose that a moral panic is a decisive intervening factor between problematization and policy response. In our case, it is likely that different policy responses would have been enacted if the discourse had emphasised the underlying socioeconomic causes of the 'problem', such as austerity measures, rising housing costs and the

\footnotetext{
2 "Since the financial catastrophe of 2008, debt has been at the heart of a moral panic. Debt - always "toxic" - was blamed for the "credit crunch": banks had created too much of it, given it to the wrong people, managed it badly, and had the temerity to turn to taxpayers to bail them out. Many people worried that, by buying debt to deal with one crisis, we were creating another". https://www.ft.com/content/bd13a1aa-60f6-11e4-b935-00144feabdc0
} 
decline in real wages witnessed since the 2008 global financial crisis (Crouch, 2011; Stiglitz, 2016). Indeed, by failing in most cases to make links to the impact of declining real wages, the newspaper discourse could be seen as another example of 'depoliticisation' (Fairclough, 2010: 243) of deeper socio-economic issues. The 'problem' was framed as a localized issue of the business practices of one small section of the finance industry, not a matter stemming from the socio-economic policies associated with the financial crisis.

\section{CONCLUSION AND IMPLICATIONS FOR FUTURE RESEARCH}

This paper has examined the discourse of payday loans in the British press in order to contribute to the theory of moral problematization and discursive delegitimation by identifying the framing role of metaphors within the delegitimation process. Our study has shown how, through the use of four root metaphors, an intense and sudden period of 'moral problematization' took place in the reporting of payday lenders that lay the ground for the construction of a moral panic. We propose that understanding metaphorical language can advance theory of the framing role of discourse in delegitimation processes in two ways. Firstly, the study reveals how metaphorical language frames issues by creating associations with pain, suffering, disease and death. Secondly, the study shows how metaphors frame issues by attributing agency to certain actors and removing or limiting agency from other actors. This discursive attribution of agency, we propose, plays a key role the ascription and removal of moral responsibility within the discourse. Moreover, we have proposed that a more critical analysis requires us to examine the ideological dimension of the discourse by examining its socio-economic and political context and consequences. What follows should therefore be read as conclusions and a suggested agenda for future research.

The findings of this study advance further the insights derived from existing work on discursive delegitimation, which has, to date, focused primarily on how neo-liberalism and globalised capital is legitimated (Vaara, et al., 2006; Vaara and Tienari, 2008; Erkama and Vaara, 2010). This literature has shown how discourse serves ideological functions by legitimating the workings of free markets as 'natural', 'inevitable' and 'right' (Fairclough, 2010: 30-37). The mass media clearly play an important role in this legitimation process by generating "the public knowledge and information, beliefs, values and attitudes which are 
necessary for establishing and sustaining economic, social and political systems and orders" (Fairclough, 2010: 468). What this study adds is a way of understanding how discourse functions to delegitimate the workings of free markets through the framing role that metaphors played in the construction of moral problematization. More specifically, what this study therefore adds, and what previous work has not yet fully developed, is an understanding of how metaphors have "consequences for how a particular issue is 'framed' or structured, which aspects are foregrounded and which backgrounded, what inferences are facilitated, what evaluative and emotional associations are triggered, what courses of action appear to be possible" (Semino, 2008: 91). While our study has focused on the UK context in particular, it has relevance across other international contexts where metaphorical language is known to play a role in the representation of business practices and the relationship between business and society, as studies of metaphorical language in the US (Hirsch, 1986), Germany (Koller, 2005) and Scandinavia (Hellgren et al., 2002; Vaara, Tienari \& Säntti, 2003; Risberg, Tienari, \& Vaara, 2003; Kuronen, Tienari \& Vaara, 2005) have shown.

In public policy contexts, Barthe (2009: 943) argues that "problematising an issue is not only saying what it is, it is indissociably also saying who has to address it, in what way and with which means". According to Lowe and Roper (2000), 'solutions' that involve government intervention are only considered permissible once the 'facts' of the problem have been established. We propose that metaphorical language constitutes an important building block in the construction of the 'fact' that a moral problem exists and therefore requires attention and intervention. From our critical standpoint, the regulation of payday loans was a convenient 'moral crusade' for the Conservative government and other neo-liberal supporters to fight, while detracting attention away from the underlying impact of recent economic policies such as austerity, decline in real wages and the deregulation of the finance sector (Kelsey et al., 2017). As Goode and Ben-Yehuda (2009) observe, moral panics enable elites to ensure that the public become concerned with "trivial or non-existent problems" ( $p$. 46), thereby "mystifying the deeper causes" (p. 64) and leaving other aspects of the economic system unquestioned. Of course, moral panics that "fan public indignation" (Goode and BenYehuda, 2009: 90) also sell newspapers more than tempered and balanced reporting. In each scandal or panic, the diagnosis and associated policy solutions are focused on individual agents, or in our case a specific industry, thus protecting the system as a whole from critique (Boltanski and Chiapello, 2005; Harvey, 2014). 


\section{REFERENCES}

Aldohni, A. K. (2013). Loan sharks v. short-term lenders: How do the law and regulators draw the line? Journal of Law and Society, 40(3), 420-449.

ACCA (2014). Payday lending: fixing a broken market. London. [Online]. Available at: http://www.accaglobal.com/content/dam/acca/global/PDF-technical/other-PDFs/poltp-pdlfab-payday-lending.pdf.

Atwood, M. (2009). Payback: Debt and the shadow side of wealth. London: Bloomsbury.

Bacchi, C. (2009). Analysing policy: What's the problem represented to be? Frenchs Forest, NSW: Pearson.

Barthe, Y. (2009). Framing nuclear waste as a political issue in France. Journal of Risk Research, 12(7-8), 941-954.

Ben-Yehuda, N. (1990). The politics and morality of deviance. Albany, NY: SUNY Press.

Billig, M. (1995). Banal nationalism. London: Sage.

Block, F. (2000). Deconstructing capitalism as a system. Rethinking Marxism, 12(3), 83-98.

Boltanski, L., \& Chiapello, E. (2005). The new spirit of capitalism. International Journal of Politics, Culture, and Society, 18(3-4), 161-188.

Brookes, G., \& Harvey, K. (2017). Just plain Wronga? A multimodal critical analysis of online payday loan discourse. Critical Discourse Studies, 14(2), 167-187.

Cassell, C. \& Bishop, V. (2014). Metaphors and sensemaking: Understanding the taint associated with dirty work. Qualitative Research in Organizations and Management: An International Journal, 9(3), 254-269.

Charteris-Black, J. (2014). Analysing political speeches: Rhetoric, discourse and metaphor. Basingstoke: Palgrave Macmillan.

Chiapello, E. (2013). Capitalism and its criticisms. In: P. Du Gay, \& G. Morgan (Eds.). New spirits of capitalism? Crises, justifications, and dynamics. Oxford: Oxford University Press, (pp. 60-81).

Chiapello, E. \& Fairclough, N. (2002). Understanding the new management ideology: A transdisciplinary contribution from critical discourse analysis and new sociology of capitalism. Discourse \& Society, 13(2), 185-208.

Chilton, P. (2004). Analysing political discourse: Theory and practice. London: Routledge.

Chouliaraki, L., \& Morsing, M. (2010). Introduction: towards an understanding of the interplay between media and organizations. In Media, organizations and identity (pp. 1-24). Palgrave Macmillan, London.

Cohen, S. (1972). Folk devils and moral panics: The creation of the mods and rockers. London: Granada Publishing Limited.

Competition and Markets Authority (2015) Payday lending market investigation: Final report. Crown. [Online]. Available at:

https://assets.publishing.service.gov.uk/media/54ebb03bed915d0cf7000014/Payday_i nvestigation_Final_report.pdf.

Cornelissen, J. P. (2005). Beyond compare: Metaphor in organization theory. Academy of Management Review, 30(4), 751-764. 
Cornelissen, J. P., Kafouros, M., \& Lock, A. R. (2005). Metaphorical images of organization: How organizational researchers develop and select organizational metaphors. Human Relations, 58(12), 1545-1578.

Cornelissen, J. P., Oswick, C., Thøger Christensen, L., \& Phillips, N. (2008). Metaphor in organizational research: context, modalities and implications for research. Organization Studies, 29(1), 7-22.

Cornelissen, J. P., \& Werner, M. D. (2014). Putting framing in perspective: A review of framing and frame analysis across the management and organizational literature. The Academy of Management Annals, 8(1), 181-235.

Couldry, N., \& Hepp, A. (2018). The mediated construction of reality. John Wiley \& Sons.

Crouch, C. (2011). The strange non-death of neo-liberalism. Cambridge: Polity.

Czarniawska, B. (2004). Narratives in social science research. London: SAGE.

Davidson, D. (2001). Essays on actions and events: Philosophical essays (vol. 1). Oxford: Oxford University Press.

Deephouse, D. L. (2000). Media reputation as a strategic resource: An integration of mass communication and resource-based theories. Journal of Management, 26(6), 1091-1112.

Dickson, T., \& McLachlan, H. V. (1989). In Search of the Spirit of Capitalism': Weber's Misinterpretation of Franklin. Sociology, 23(1), 81-89.

Durand, R. \& McGuire, J. (2005). Preface: Fading legitimacies in organized contexts. International Studies of Management \& Organization, 34(4), 3-6.

Engelen, E., Erturk, I., Froud, J., Johal, S., Lever, A., Moran, M., \& Williams, K. (2012). Misrule of experts? The financial crisis as elite debacle. Economy and Society, 41, 360-382.

Entman, R. M. (1993). Framing: Toward clarification of a fractured paradigm. Journal of communication, 43(4), 51-58.

Entman, R. M. (2004). Projections of power: Framing news, public opinion, and US foreign policy. University of Chicago Press.

Entman, R. M. (2007). Framing bias: Media in the distribution of power. Journal of communication, 57(1), 163-173.

Erkama, N. \& Vaara, E. (2010). Struggles over legitimacy in global organizational restructuring: A rhetorical perspective on legitimation strategies and dynamics in a shutdown case. Organization Studies, 31(7), 813-839.

Fairclough, N. (2001). Language and power. Harlow: Pearson Education.

Fairclough, N. (2010). Critical discourse analysis: The critical study of language (2 $\left.2^{\text {nd }} e d\right)$. Harlow: Pearson.

Financial Conduct Authority (2014) Detailed rules for the price cap on high-cost short-term credit. [Online]. Available at: http://www.fca.org.uk/static/documents/policystatements/ps14-16.pdf.

Financial Conduct Authority (2016) Consumer credit register. Available at: https://www.thefca.org.uk/firms/consumer-credit-register (Accessed: 16 June 2016).

Frye, N. (1973/1957). Anatomy of criticism. Princeton: Princeton University.

Gamson, W. A., Croteau, D., Hoynes, W., \& Sasson, T. (1992). Media images and the social construction of reality. Annual Review of Sociology, 18(1), 373-393.

Gamson, W. A., \& Modigliani, A. (1989). Media discourse and public opinion on nuclear power: A constructionist approach. American journal of sociology, 95(1), 1-37.

Giger, N., \& Nelson, M. (2011). The electoral consequences of welfare state retrenchment: Blame avoidance or credit claiming in the era of permanent austerity? European Journal of Political Research, 50(1), 1-23. 
Gillespie, N., \& Owen, G. (2013). Restoring Trust in the Financial Services Sector. A report published by the Industry and Parliament Trust. London.

Goatly, A. (1997). The language of metaphors. New York: Routledge.

Goode, E. \& Ben-Yehuda, N. (2009). Moral panics: The social construction of deviance. Malden, MA: Wiley-Blackwell.

Grant, D. \& Oswick, C. (1996). Introduction: Getting the measure of metaphors. In D. Grant \& C. Oswick (Eds.), Metaphor and organizations (pp. 1-20). London: SAGE.

Graeber, D. (2014). Debt: the first 5,000 years. Brooklyn, N.Y.: Melville House.

Grafström, M., \& Windell, K. (2011). The role of infomediaries: CSR in the business press during 2000-2009. Journal of business ethics, 103(2), 221.

Harré, R. (1995). Agentive discourse. In R. Harré \& P. Stearns (Eds.), Discourse psychology in practice (pp. 120-136). London: Sage.

Harré, R. \& van Langenhove, L. (1999). The dynamics of social episodes. In: R. Harré \& L. van Langenhove (Eds.), Positioning theory: Moral contexts of intentional action (pp. 1-13). Oxford: Basil Blackwell.

Hart, C. (2008). Critical discourse analysis and metaphor: Toward a theoretical framework. Critical Discourse Studies, 5(2), 91-106.

Hartz, R. \& Steger, T. (2010). Heroes, villains and 'honourable merchants': Narrative change in the German media discourse on corporate governance. Organization, 17(6), 767-785.

Harvey, D. (2014). Seventeen contradictions and the end of capitalism. Oxford: Oxford University Press.

Hawdon, J. E. (2001). The role of presidential rhetoric in the creation of a moral panic: Reagan, Bush, and the war on drugs. Deviant Behavior, 22(5), 419-445.

Hellgren, B., Lowstedt, J., Puttonen, L., Tienari, J., Vaara, E. \& Werr, A. (2002). How issues become (re)constructed in the media: Discursive practices in the AstraZeneca merger. British Journal of Management, 13(2), 123-140.

Hirsch, M. (1986). From ambushes to golden parachutes: Corporate takeovers as an instance of cultural framing and institutional integration. American Journal of Sociology, 91(4), 800-837.

Hudson, B. A. (2008). Against all odds: A consideration of core-stigmatized organizations. Academy of Management Review, 33(1), 252-266.

Inns, D. (2002). Metaphor in the literature of organizational analysis: A preliminary taxonomy and a glimpse at a humanities-based perspective. Organization, 9(2), 305-330.

Jonsson, S., Greve, H. R. \& Fujiwara-Greve, T. (2009). Undeserved loss: The spread of legitimacy loss to innocent organizations in response to reported corporate deviance. Administrative Science Quarterly, 54(2), 195-228.

Jørgensen, M. \& Phillips, L. (2002). Discourse analysis as theory and method. London; Thousand Oaks, CA.: SAGE.

Kelsey, D., Mueller, F., Whittle, A. \& KhosraviNik, M. (2017). Financial crisis and austerity: Interdisciplinary concerns in critical discourse studies. In: Kelsey, D., Mueller, F., Whittle, A. \& KhosraviNik, M. (2017). The discourse of financial crisis and austerity: Critical analyses of business and economics across disciplines. London: Routledge, pp. 1-19.

Koller, V. (2005). Critical discourse analysis and social cognition: Evidence from business media discourse. Discourse \& Society, 16(2), 199-224.

Kostera, M., \& Glinka, B. (2001). Budget as logos: The rhetorics of the Polish press. Organization, 8(4), 647-682. 
Kuronen, M-L., Tienari, J. \& Vaara, E. (2005). The merger storm recognizes no borders: An analysis of media rhetoric on a business manoeuvre. Organization, 12(2), 247-273.

Lakoff, G. (2008). The Political Mind. Viking Books

Lakoff, G. (1990). Women, fire, and dangerous things: What categories reveal about the mind. Chicago and London: University of Chicago Press.

Lakoff, G. \& Johnson, M. (1980). Metaphors we live by. Chicago: University of Chicago Press.

Lazzarato, M. (2012). The making of the indebted man: An essay on the neoliberal condition. Los Angeles, CA.: Semiotext(e).

Leyshon, A., Burton, D., Knights, D., Alferoff, C., \& Signoretta, P. (2004). Towards an ecology of retail financial services: understanding the persistence of door-to-door credit and insurance providers. Environment and Planning A, 36(4), 625-645.

Leyshon, A., Signoretta, P., Knights, D., Alferoff, C., \& Burton, D. (2006). Walking with moneylenders: the ecology of the UK home-collected credit industry. Urban studies, 43(1), 161-186.

Lowe, A. (2001). Reform of the New Zealand health system: Problematization, mobilization and change. Policy Studies, 22(3-4), 233-249.

Lowe, A. \& Roper, J. (2000). Share-market regulation in New Zealand: The problematisation of takeovers legislation. Policy Studies, 21(2), 115-132.

Lule, J. (2001). Daily news, eternal stories: The mythological role of journalism. New York: The Guilford Press.

Marron, D. (2014). "Informed, educated and more confident": Financial capability and the problematization of personal finance consumption. Consumption Markets \& Culture, 17(5), 491-511.

Mueller, F., Carter, C., \& Whittle, A. (2015). Can audit (still) be trusted? Organization Studies, 36(9), 1171-1203.

Office of Fair Trading (2013) Payday lending compliance review final report. [Online]. Available at:

https://assets.publishing.service.gov.uk/media/532ad55eed915d0e5d00038d/oft1481. pdf (Accessed: 3 October 2016).

Oswick, C., Keenoy, T., \& Grant, D. (2002). Metaphor and analogical reasoning in organization theory: beyond orthodoxy. Academy of Management Review, 27(2), 294-303.

Packman, C. (2014). Payday lending: Global growth of the high-cost credit market. New York: Palgrave Macmillan.

Patriotta, G., Gond, J. P., \& Schultz, F. (2011). Maintaining legitimacy: Controversies, orders of worth, and public justifications. Journal of Management Studies, 48(8), 1804-1836.

Peebles, G. (2013). Washing away the sins of debt: The nineteenth-century eradication of the debtors' prison. Comparative Studies in Society and History, 55(3), 701-724.

Penaloza, L. \& Barnhart, M. (2011). Living US capitalism: The normalization of credit/debt. Journal of Consumer Research, 38(4), 743-762.

Phillips, N., \& Hardy, C. (1997). Managing multiple identities: Discourse, legitimacy and resources in the UK refugee system. Organization, 4(2), 159-185.

Prasad, P., Prasad, A., \& Baker, K. (2016). Smoke and mirrors: Institutional entrepreneurship and gender identities in the US Tobacco Industry, 1920-1945. Organization, 23(2), 227249.

Riad, S. \& Vaara, E. (2011). Varieties of national metonymy in media accounts of international mergers and acquisitions. Journal of Management Studies, 48(4), 737-771. 
Riaz, S., Buchanan, S. \& Bapuji, H. (2011). Institutional work amidst the financial crisis: Emerging positions of elite actors. Organization, 18(2), 187-214.

Risberg, A., Tienari, J. \& Vaara, E. (2003). Making sense of a transnational merger: Media texts and the (re)construction of power relations. Culture and Organization, 9(2), 121-137.

Ritchie, L. D. (2013). Metaphor. Cambridge: Cambridge University Press.

Scheufele, D. A. (1999). Framing as a theory of media effects. Journal of communication, 49(1), 103-122.

Scheufele, D. A. \& Tewksbury, D. (2006). Framing, agenda setting, and priming: The evolution of three media effects models. Journal of communication, 57(1), 9-20.

Semino, E. (2008). Metaphor in discourse. Cambridge: Cambridge University Press.

Snow, D. A., \& Benford, R. D. (1988). Ideology, frame resonance and participant mobilization. International Social Movement Research, 1(1), 197-217.

Stanley, L., Mackenzie Davey, K. \& Symon, G. (2014). Exploring media construction of investment banking as dirty work. Qualitative Research in Organizations and Management: An International Journal, 9(3), 270-287.

Stiglitz, J. (2010). Freefall: Free Markets and the Sinking of the Global Economy. London: Penguin

Stiglitz, J. (2016). The great divide. London: Penguin.

Street, J. (2010). Mass media, politics and democracy. Palgrave Macmillan.

Suchman, M. C. (1995). Managing legitimacy: strategic and institutional approaches. Academy of Management Review, 20(3), 571-610.

Suddaby, R. \& Greenwood, R. (2005). Rhetorical strategies of legitimacy. Administrative Science Quarterly, 50(1), 35-67.

Tankard Jr, J. W. (2001). The empirical approach to the study of media framing. In Reese, S. D., Gandy Jr, O. H., \& Grant, A. E. (Eds.). (2001). Framing public life: Perspectives on media and our understanding of the social world, pp. 111-121. Routledge.

The Guardian website (2008) Elevator pitch: Wonga fixes that cash problem. Available at: http://www.theguardian.com/media/pda/2008/jul/23/elevatorpitchwongafixestha (Accessed: 18 April 2016).

Tinker, T. (1986). Metaphor or reification: Are radical humanists really libertarian anarchists? Journal of Management Studies, 23(4), 363-384.

Toulmin, S. E., Rieke, R. D. \& Janik, A. (1979). An introduction to reasoning. New York: Macmillan.

Tourish, D. \& Hargie, O. (2012). Metaphors of failure and the failures of metaphor: A critical study of root metaphors used by bankers in explaining the banking crisis. Organization Studies, 33(8), 1045-1069.

Tregidga, H. (2013). Biodiversity offsetting: Problematisation of an emerging governance regime. Accounting, Auditing \& Accountability Journal, 26(5), 806-832.

Trentmann, F. (2016). Empire of things. London: Allen Lane.

Ureta, S. (2014). Policy assemblages: Proposing an alternative conceptual framework to study public action. Policy Studies, 35(3), 303-318.

Vaara, E. (2014). Struggles over legitimacy in the Eurozone crisis: Discursive legitimation strategies and their ideological underpinnings. Discourse \& Society, 25(4), 500-518.

Vaara, E. \& Monin: (2010). A recursive perspective on discursive legitimation and organizational action in mergers and acquisitions. Organization Science, 21(1), 3-22.

Vaara, E. \& Tienari, J. (2002). Justification, legitimization and naturalization of mergers and acquisitions: A critical discourse analysis of media texts. Organization, 9(2), 275-304. 
Vaara, E. \& Tienari, J. (2008). A discursive perspective on legitimation strategies in multinational corporations. Academy of Management Review, 33(4), 985-993.

Vaara, E. \& Tienari, J. (2011). On the narrative construction of multinational corporations: An antenarrative analysis of legitimation and resistance in a cross-border merger. Organization Science, 22(2), 370-390.

Vaara, E., Kleymann, B. \& Seristö, H. (2004). Strategies as discursive constructions: The case of airline alliances. Journal of Management Studies, 41(1), 1-35.

Vaara, E., Tienari, J. \& Laurila, J. (2006). Pulp and paper fiction: On the discursive legitimation of global industrial restructuring. Organization Studies, 27(6), 789-810.

Vaara, E., Tienari, J. \& Säntti, R. (2003). The international match: metaphors as vehicles of social identity-building in cross-border mergers. Human Relations, 56(4), 419-451.

Vallgarda, S. (2008). Social inequality in health: dichotomy or gradient? A comparative study of problematizations in national public health programmes. Health Policy, 85, 71-82.

Van Leeuwen, T. (2007). Legitimation in discourse and communication. Discourse \& Communication, 1(1), 91-112.

Van Dijk, T. A. (1998). Ideology: A multidisciplinary approach. London: Sage.

Vasterman, P. L. (2005). Media-hype: Self-reinforcing news waves, journalistic standards and the construction of social problems. European Journal of Communication, 20(4), 508-530.

Weber, M. (1967). The Protestant ethic and the 'spirit' of capitalism. London: Unwin.

Welch, M., Price, E. A., \& Yankey, N. (2002). Moral panic over youth violence: Wilding and the manufacture of menace in the media. Youth \& Society, 34(1), 3-30.

Whittle, A., \& Mueller, F. (2016). Accounting for the banking crisis: Repertoires of agency and structure. Critical Discourse Studies, 13(1), 20-40.

Whittle, A., \& Mueller, F. (2012). Bankers in the dock: Moral storytelling in action. Human Relations, 65(1), 111-139.

Wilkins, L., \& Coleman, R. (2005). The moral media: How journalists reason about ethics. Mahwah, NJ: Lawrence Erlbaum.

Zuckerman, E. W. (1999). The categorical imperative: Securities analysts and the illegitimacy discount. American Journal of Sociology, 104(5), 1398-1397. 


\begin{tabular}{|l|l|c|}
\hline \multicolumn{2}{|c|}{ Monthly Print and Online Readership } \\
\hline \multicolumn{1}{|c|}{ Title } & \multicolumn{1}{|c|}{ Website } & $\begin{array}{c}\text { Net Print + Website } \\
\text { Total (000s) }\end{array}$ \\
\hline Daily Mail/The Mail on Sunday & dailymail.co.uk & 21571 \\
The Sun/The Sun on Sunday & thesun.co.uk & 16654 \\
Daily Mirror/Sunday Mirror/Sunday People & mirror.co.uk & 13739 \\
The Guardian/The Observer & theguardian.com & 12665 \\
Metro & metro.co.uk & 12471 \\
The Daily Telegraph/The Sunday Telegraph & telegraph.co.uk & 12229 \\
\hline The Independent/The Independent on Sunday/i & independent.co.uk & 8377 \\
The Times/The Sunday Times & thetimes.co.uk/thesundaytimes.co.uk & 7128 \\
Daily Express/Sunday Express & express.co.uk & 6504 \\
London Evening Standard & standard.co.uk & 5406 \\
Daily Star/Daily Star Sunday & dailystar.co.uk & 4856 \\
Daily Record/Sunday Mail (Scotland) & dailyrecord.co.uk & 2800 \\
Financial Times & ft.com & 2403 \\
The Scotsman/Scotland on Sunday & scotsman.com & 1264 \\
The Herald (Scotland)/Sunday Herald (Scotland) & heraldscotland.com & 956 \\
Yorkshire Post & yorkshirepost.co.uk & 769 \\
The Courier - Dundee & thecourier.co.uk & 488 \\
Glasgow Evening Times & eveningtimes.co.uk & 430 \\
\hline
\end{tabular}

Figure 1 Print and online readership data, Jan-Dec 2013

(Source: National Readership Survey, 2014) 


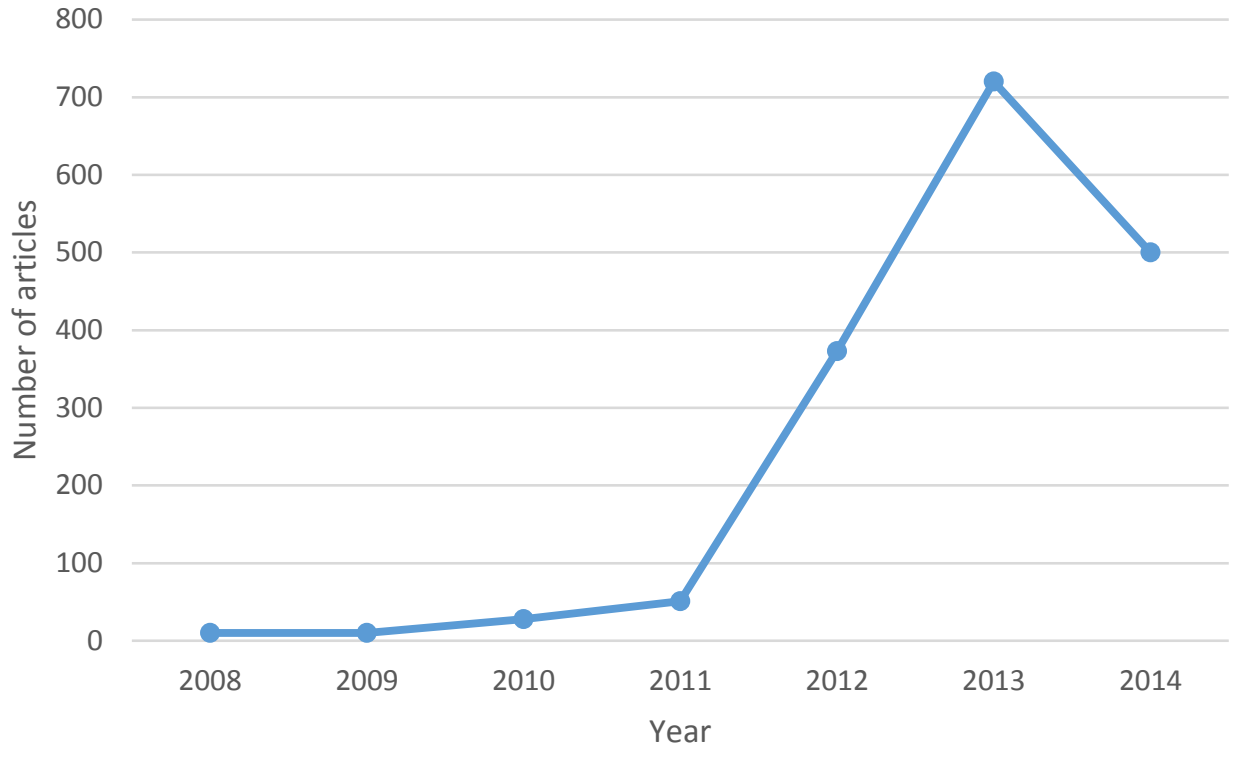

Figure 2 Newspaper articles by year (2008-2014) 


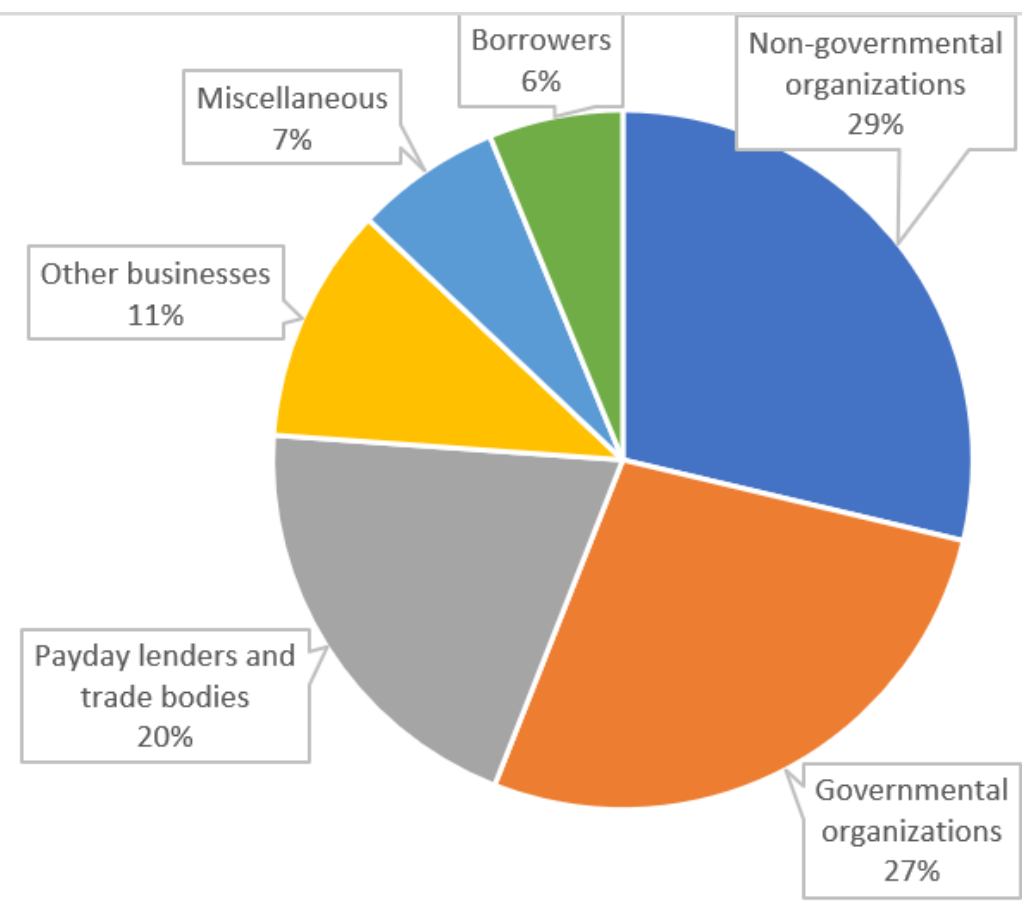

Figure 3 Sources of direct quotations (2008-2014) 


\begin{tabular}{|c|c|c|}
\hline Year & $\begin{array}{l}\text { Data-set } \\
\text { (no. articles) }\end{array}$ & $\begin{array}{l}\text { Sample } \\
\text { (no. articles) }\end{array}$ \\
\hline $2008-2011$ & 99 & 99 \\
\hline 2012 & 373 & 117 \\
\hline 2013 & 720 & 120 \\
\hline 2014 & 500 & 120 \\
\hline Total & 1693 & 456 \\
\hline
\end{tabular}

Table 1 Data-set and sample analysed

\begin{tabular}{|l|l|l|l|l|l|l|l|}
\hline & Sun & Mirror & Guardian & Telegraph & Metro & Daily Mail & Total \\
\hline $\begin{array}{l}\text { Predators \& } \\
\text { parasites }\end{array}$ & 64 & 102 & 82 & 31 & 15 & 66 & $\mathbf{3 6 0}$ \\
\hline Orientation & 58 & 101 & 72 & 17 & 18 & 70 & $\mathbf{3 3 6}$ \\
\hline Warfare & 21 & 33 & 30 & 12 & 8 & 29 & $\mathbf{1 3 3}$ \\
\hline Pathology & 25 & 28 & 23 & 7 & 10 & 29 & $\mathbf{1 2 2}$ \\
\hline Total & $\mathbf{1 6 8}$ & $\mathbf{2 6 4}$ & $\mathbf{2 0 7}$ & $\mathbf{6 7}$ & $\mathbf{5 1}$ & $\mathbf{1 9 4}$ & $\mathbf{9 5 1}$ \\
\hline
\end{tabular}

Table 2 Frequency of metaphors across newspaper sample analysed 


\begin{tabular}{|c|c|c|c|}
\hline Metaphor & Illustrative Examples & Framing role & Problematization \\
\hline Predators & $\begin{array}{l}\text { "...is just one of the 'legal loan shark' firms that will be circling cash-strapped adults this } \\
\text { Christmas." (Mail on Sunday, } 30 \text { Oct 2011) } \\
\text { "Creasy said: 'This isn't broken Britain, but broke Britain - and it is being bled dry by the legal } \\
\text { loan shark industry and their interest rates of } 1,700 \% \text { or more.'" (The Guardian, } 8 \text { Dec } \\
\text { 2011) } \\
\text { "[Paul Lynam, Secure Trust Bank] said: 'When fundamentally credit-worthy individuals try to } \\
\text { extricate themselves from the payday loan web, the lender is in no rush to help." (Mail on } \\
\text { Sunday, } 11 \text { Nov } 2012 \text { ) } \\
\text { "THE plight of hard-up families snared by payday loan sharks is one of the saddest aspects of } \\
\text { Christmas." (The Sun, } 23 \text { Dec } 2012 \text { ) } \\
\text { "Today's announcement means yet again these sharks have slipped through the net." (Stella } \\
\text { Creasy cited in The Guardian, } 11 \text { Nov 2014) } \\
\text { "PAYDAY lenders are prepared to pay up } \mathrm{f} 100 \text { to get their claws into each new customer." } \\
\text { (The Mirror, } 14 \text { Feb } 2013 \text { ) } \\
\text { "What we are seeing in } 2013 \text { is vulture capitalism, picking wallets and purses clean." } \\
\text { (McCluskey cited in Metro, } 4 \text { Sep 2013) }\end{array}$ & $\begin{array}{l}\text { The 'loan shark' metaphor } \\
\text { conjures up an image of a } \\
\text { dangerous and bloodthirsty } \\
\text { creature. } \\
\text { Lenders are presented as } \\
\text { 'vultures', } \\
\text { feasting on carcasses. } \\
\text { Lenders are described as } \\
\text { 'getting their claws' into } \\
\text { borrowers, being able to } \\
\text { possess and control } \\
\text { borrowers. }\end{array}$ & $\begin{array}{l}\text { Lenders are predators } \\
\text { who control borrowers } \\
\text { and profit from their } \\
\text { misfortune. }\end{array}$ \\
\hline
\end{tabular}




\begin{tabular}{|c|c|c|c|}
\hline & (Metro, 21 Mar 2014) & & \\
\hline Parasites & $\begin{array}{l}\text { "LOAN PARASITES; LENDERS CHARGE UP TO 4,400\%" (The Mirror, } 4 \text { Nov 2010) } \\
\text { "But since then we have exposed the ruthless payday parasites targeting soldiers returning } \\
\text { from the frontline and struggling students with loans that can cost up to 5,700\% in annual } \\
\text { interest." (The Mirror, } 25 \text { Feb 2012) } \\
\text { "Hopefully, this is the beginning of a root and branch overhaul of a parasitic industry that } \\
\text { shames Britain." (The Mirror, } 25 \text { Feb 2012) } \\
\text { "CONSUMER FOCUS slammed the company for "leeching" cash off Brits." (The Sun, } 9 \text { Mar } \\
\text { 2012) }\end{array}$ & $\begin{array}{l}\text { These metaphors suggest } \\
\text { that the pests [lenders] ruin } \\
\text { the environment. }\end{array}$ & $\begin{array}{l}\text { Lenders are pests in } \\
\text { society that need to be } \\
\text { controlled. }\end{array}$ \\
\hline
\end{tabular}

Table 3 Predator and parasite metaphors 


\begin{tabular}{|c|c|c|c|}
\hline Metaphor & Illustrative Examples & Framing role & Problematization \\
\hline $\begin{array}{l}\text { Upwards/ } \\
\text { outwards }\end{array}$ & $\begin{array}{l}\text { "Taking out a payday loan is a kind of financial Russian roulette which is devastating scores of } \\
\text { families. Fail to pay back what you have borrowed after a month, and the loan starts to build } \\
\text { up a horrific pile of interest many times the original sum." (Daily Mail, } 8 \text { Dec 2011) } \\
\text { "If you ask to extend the loan, be aware that interest will mount up, and Wonga will allow you } \\
\text { to do this only three times." (The Sunday Telegraph, } 24 \text { Jun 2012) } \\
\text { "A GRANDAD killed himself after his } £ 20,000 \text { payday loan debts spiralled out of control, an } \\
\text { inquest heard." (The Sun, } 22 \text { Jul } 2014 \text { ) }\end{array}$ & $\begin{array}{l}\text { The notion of debts piling and } \\
\text { mounting up and spiralling } \\
\text { out of control takes } \\
\text { responsibility away from the } \\
\text { individual debtor, as the debt } \\
\text { has moved beyond their } \\
\text { control. }\end{array}$ & $\begin{array}{l}\text { The borrower is not } \\
\text { responsible for the } \\
\text { increase in debt size. }\end{array}$ \\
\hline Expansion & $\begin{array}{l}\text { "But pay day lending has rocketed in recent years, rising from } f 100 \text { million in } 2004 \text { to } f 1.7 b i l l i o n \\
\text { in 2010." (The Sun, } 17 \text { Jun 2012) } \\
\text { "The claim will stun MPs furious over Wonga's breakneck expansion in the UK." (The Sun, } 20 \text { Nov } \\
\text { 2012) } \\
\text { "In recent years there has been an explosion in the payday lending market which has more than } \\
\text { doubled in size to over } £ 2 \text { bn." (Sun on Sunday, } 27 \text { Oct 2013) }\end{array}$ & $\begin{array}{l}\text { The use of the terms } \\
\text { "rocketed" and "explosion" } \\
\text { also portray the increase as } \\
\text { incredibly rapid and } \\
\text { powerful, to the extent that it } \\
\text { is even dangerous. }\end{array}$ & $\begin{array}{l}\text { Lenders are out of } \\
\text { control. }\end{array}$ \\
\hline Downwards & $\begin{array}{l}\text { "Almost one in three borrowers can't repay on time, and they get sucked into a downward spiral } \\
\text { of debt." (The Mirror, } 4 \text { Oct 2013) }\end{array}$ & $\begin{array}{l}\text { Images of falling downwards } \\
\text { take away agency from } \\
\text { debtors and present them as }\end{array}$ & $\begin{array}{l}\text { Lenders are sucking } \\
\text { consumers into debt. }\end{array}$ \\
\hline
\end{tabular}




\begin{tabular}{|c|c|c|c|}
\hline & $\begin{array}{l}\text { "[Citizens Advice Scotland] said: 'It's bad enough that so many people are falling into debt } \\
\text { through the actions of some payday lenders - which, of course, remains a big issue."' (Metro, } \\
27 \text { Aug 2014) }\end{array}$ & $\begin{array}{l}\text { being subject to gravitational } \\
\text { forces. }\end{array}$ & \\
\hline Entrapment & $\begin{array}{l}\text { "[Credit Action] said: 'Not only are they much more expensive than other forms of credit, we are } \\
\text { increasingly seeing payday loans causing people to get into a debt hole they are unable to get } \\
\text { out of.'" (The Guardian, } 6 \text { Dec 2008) } \\
\text { "The tactic used by a number of payday loan firms aims to maximise profits by effectively locking } \\
\text { in hard-pressed borrowers for extended periods." (Mail on Sunday, } 11 \text { Nov 2012) } \\
\text { "VICTORY OVER ROLL-OVER LOANS; We get Wonga to stop saddling people with more debt" } \\
\text { (The Mirror, } 14 \text { July 2013) } \\
\text { "The industry has been heavily criticised in recent months amid claims that it is pushing families } \\
\text { into debts they cannot afford to pay back." (Daily Mail, } 23 \text { May 2014) }\end{array}$ & $\begin{array}{l}\text { Notions of being trapped, } \\
\text { contained, saddled down, } \\
\text { locked or pushed invoke } \\
\text { images of individuals who are } \\
\text { unable to remove themselves } \\
\text { from the debt. }\end{array}$ & $\begin{array}{l}\text { Lenders are trapping } \\
\text { consumers in debt. }\end{array}$ \\
\hline
\end{tabular}

Table 4 Orientation metaphors 


\begin{tabular}{|c|c|c|c|}
\hline Metaphor & Illustrative Examples & Framing role & Problematization \\
\hline Invasion & $\begin{array}{l}\text { "These American imports are effectively a cash advance on money expected at the end of the } \\
\text { month" (The Mirror, } 8 \text { April 2008) } \\
\text { "LOAN SHARK INVASION. Worried MPs launch bid to block global advance of the payday lenders } \\
\text { charging 4,000\% interest" (Mail on Sunday, } 13 \text { Mar 2011) } \\
\text { "Campaigners say that by taking a softer line, UK regulators have allowed borrowers here to } \\
\text { become easy targets." (Mail on Sunday, } 28 \text { April 2013) } \\
\text { "[Movement for Change] says: 'Many of the lenders are backed by companies from overseas. In } \\
\text { the US, the introduction of tighter regulation led many companies to seek easier markets - } \\
\text { and they found one in the UK."' (Mail on Sunday, } 28 \text { April 2013) }\end{array}$ & $\begin{array}{l}\text { Firms were categorized as } \\
\text { foreign invaders, attracted by } \\
\text { comparatively lax regulatory } \\
\text { structures. }\end{array}$ & Lenders are aliens. \\
\hline Violence & $\begin{array}{l}\text { "Many lenders will hit you with large fees if you need extra time to pay back your loan." (Daily } \\
\qquad \text { Mail, } 31 \text { Jan 2012) } \\
\text { “...then slapping [customers] with a charge for late repayment" (The Guardian, } 15 \text { Feb 2013) } \\
\text { “...companies bombarding customers with emails and texts to pay back debts” (The Mirror, } 16 \\
\text { Feb 2013) }\end{array}$ & $\begin{array}{l}\text { Lenders are described as } \\
\text { aggressive and fighting } \\
\text { existing firms, causing harm. }\end{array}$ & $\begin{array}{l}\text { Lenders engage in } \\
\text { aggressive behaviour. }\end{array}$ \\
\hline
\end{tabular}




\begin{tabular}{|c|c|c|c|}
\hline $\begin{array}{l}\text { Moral } \\
\text { battle }\end{array}$ & $\begin{array}{l}\text { "Fisher said the OFT had acted because the company's directors were largely all still in place - } \\
\text { and it couldn't be trusted. He said: 'This is the nuclear option.'" (The Sun, } 9 \text { Mar 2012) } \\
\text { "The scourge of payday lenders should be stamped on hard." (Mail on Sunday, } 12 \text { May 2013) } \\
\text { "BORROWERS ARE FIGHTING BACK AGAINST UNSCRUPULOUS LENDERS" (Mail on Sunday, } 27 \\
\text { April 2014) } \\
\text { "THE battle against unscrupulous payday lenders has stepped up a gear with new campaigns and } \\
\text { tougher regulation." (Mail on Sunday, } 27 \text { April 2014) } \\
\text { "This led them to join forces to run a local campaign warning about the dangers of payday } \\
\text { lending." (Mail on Sunday, } 27 \text { April 2014) } \\
\text { “...the company came under sustained attack from politicians and Justin Welby" (The Guardian, } \\
23 \text { May 2014) } \\
\text { "FORMER City regulator Sir Hector Sants is leading a task force of churches, community groups } \\
\text { and credit unions taking on payday lenders." (Metro, 29 May 2014) } \\
\text { "...the new chairman of embattled payday lender Wonga" (The Observer, } 17 \text { Aug 2014) } \\
\text { "Stella Creasy, who led the charge against the likes of Wonga, ..." (The Guardian, 11 Nov 2014) }\end{array}$ & $\begin{array}{l}\text { Lenders are described as an } \\
\text { enemy. A moral battle ensues } \\
\text { between opposing forces of } \\
\text { good and evil. }\end{array}$ & $\begin{array}{l}\text { Lenders are an enemy } \\
\text { of the people. }\end{array}$ \\
\hline
\end{tabular}

\section{Table 5 Warfare metaphors}




\begin{tabular}{|c|c|c|c|}
\hline Metaphor & Illustrative Examples & Framing role & Problematization \\
\hline Pain & $\begin{array}{l}\text { “...charges for late payment are designed to sting" (The Sunday Telegraph, } 9 \text { Aug 2009) } \\
\text { "PAIN DAY LOANS" (The Mirror, } 8 \text { Dec 2011) } \\
\text { “...they can be crippling if not paid off” (The Mirror, } 8 \text { Dec 2011) } \\
\text { “...firm's 2,689\% rate drilling into customer pockets" (The Mirror, } 22 \text { Sep 2011) } \\
\text { "Payday loan debts killed our son" (The Sun, } 30 \text { May 2012) } \\
\text { “...thousands of families will feel the pain after borrowing from these loan companies" (The } \\
\text { Mirror, } 31 \text { Dec 2013) } \\
\text { "Borrowers hurt by high payday loan default fees" (Metro, } 13 \text { Jan 2014) }\end{array}$ & $\begin{array}{l}\text { Payday loans are presented } \\
\text { as a source of pain and } \\
\text { suffering, even death. }\end{array}$ & $\begin{array}{l}\text { Payday lenders' } \\
\text { practices are causing } \\
\text { harm to society. }\end{array}$ \\
\hline Toxin & $\begin{array}{l}\text { "[Payday loans] should come with a health warning" (The Observer, } 29 \text { Jun 2008) } \\
\text { "WONGA FEEDS OFF BROWN'S TOXIC LEGACY" (Mail on Sunday, } 13 \text { May 2012) } \\
\text { "'[These loans] should come with a bargepole warning.'” (The Sun, } 10 \text { Oct 2012) } \\
\text { "[Creasy] raged: 'This is further damning evidence of how toxic this industry is.'” (The Sun, } 17 \text { Oct } \\
2012 \text { ) }\end{array}$ & $\begin{array}{l}\text { Payday loan industry is } \\
\text { presented as an addictive } \\
\text { and damaging toxic chemical. }\end{array}$ & $\begin{array}{l}\text { Payday lenders are } \\
\text { poisonous to society. }\end{array}$ \\
\hline
\end{tabular}




\begin{tabular}{|c|c|c|c|}
\hline & $\begin{array}{l}\text { "'We [My Community Bank] are an antidote to the addictive and expensive types of loan offered } \\
\text { by payday lenders."” (The Sun, } 27 \text { Nov 2013) }\end{array}$ & & \\
\hline Epidemic & $\begin{array}{l}\text { “END PLAGUE OF PAYDAY LOAN ADVERTS” (Mail on Sunday, } 12 \text { May 2013) } \\
\text { “[Paul Blomfield MP] said: 'These shocking figures show the scale of the payday lending epidemic. } \\
\text { Their corrosive impact is then often exacerbated by the companies clustering their shops in } \\
\text { areas of higher deprivation.'” (The Guardian, } 13 \text { Mar 2014) }\end{array}$ & $\begin{array}{l}\text { Payday loan industry is } \\
\text { presented as an out of } \\
\text { control disease that is } \\
\text { wreaking havoc, beyond the } \\
\text { control of borrowers. }\end{array}$ & $\begin{array}{l}\text { Payday lenders are an } \\
\text { out of control } \\
\text { outbreak. }\end{array}$ \\
\hline
\end{tabular}

Table 6 Pathology metaphors 